\title{
Research on Cultivation of Business English Talents in Application-oriented Colleges and Universities for Cross-Boarder E-commerce on the "Internet +" Basis
}

\author{
Xuan Chen ${ }^{1, a}$ and Zhenhua Chen ${ }^{2, b}$
}

Xiangnan University, Chenzhou, Hunan, 423000, China

Keywords: Internet +; Business English; Cross-boarder e-commerce; Talent cultivation

\begin{abstract}
With the rapid development of international cross-boarder e-commerce, the training of compound and applied talent for Business English faces new requirements and challenges. Currently, there exist many problems in training business English talent of application-oriented colleges and universities, such as the unscientific cultivating programs for business English talents, infeasible course arrangement, emphasizing on theoretical teaching while ignoring practical teaching, and the lack of "double-professionally-titled" teachers. Under the "internet + " basis background, business English teaching should focus on cultivating application-oriented business English talent by the way of building new curriculum system and teaching modes, and strengthening practical training and teacher's team-building.
\end{abstract}

\section{Introduction}

Nowadays, with the rapid development of internet, cross-border e-commerce has sprung up and become a strong force in China's import and export trade. By 2020, China's transaction scale of cross-border e-commerce will reach 12 trillion yuan, accounting for about $37.6 \%$ of China's total imports and exports. As the development of cross-border e-commerce, the demand for compound applied business talents is rapidly increasing, and our society needs more than 1.5 billion specialized cross-border e-commerce business talents in recent years. With its proficient English skill, broad international vision and clear intercultural communication consciousness, business English talent has ushered in a rare opportunity for development. On the other hand, as cross-border e-commerce platform has a certain impact on traditional trade mode, it raises new requirements for the training of business English talents. Therefore, the training target, teaching models and methods of business English majors in application-oriented universities should be adjusted accordingly to cope with changes in market demand.

\section{New Requirements for Cultivating Business English Talent for Cross-border E-commerce under Background of "Internet +"}

On Several opinions on the reform of undergraduate education for foreign language majors in twenty-first Century, the ministry of education clearly pointed out: "the single foreign language professional talents can not adapt to the needs of the market economy, and foreign language majors must be changed from the single academic approach training mode to the applied and compound talents training mode".[1] Nowadays, what our society needs is the compound and applied business English talent with good English language skills, rich business knowledge, certain cross-cultural communication ability, and proficiently using modern information technology.

Cross-border e-commerce is a new mode of international trade and has changed the traditional mode of international trade. The trade bodies in different countries make transaction and effect payment online through the internet transaction platform and deliver the goods by cross-border logistics. Cross-border e-commerce talent should not only be proficient in the basic English and business skills, but also need to understand the knowledge, resources and practical operations of cross-border e-commerce, such as understanding import and export trade, warehouse management and cross-border logistics operation, and mastering overseas channels expansion, cross-border payment and transnational management methods. In addition, they should also understand the rules 
and operation of Alibaba, Amazon, eBay and other electronic business platform, know how to analyze the demand at home and abroad and promote the products, and even need to know how to design and modify web pages and advertisement through photoshop. All in all, in the context of cross-border e-commerce, the demand of business English talent tends to be diversified and comprehensive.

\section{The Problems of Cultivating Business English Talent for Cross-border E-commerce}

Unscientific Design of Talents Training Plan. Professional curriculum fails to form a butt joint with social HR market. At present, business English teaching in most application-oriented universities emphasizes the training of language skills, while neglects the cultivation of business practice skills, thus leading to the lack of ability to practice for college students. And many application-oriented universities set up business English courses according to business English talent training plan of comprehensive or financial universities, which is not suitable for cultivating applied talents. Usually, business English courses are mainly the traditional English language skills and business knowledge courses. And English language skills courses account for more than 50\%, while business knowledge courses account for about 30\%, like international trade theory and practice, international commercial law, marketing, foreign trade correspondence, etc. All the business knowledge courses rarely involve cross-border e-commerce knowledge, and textbooks can not be updated with the development of trade modes. Besides, few application-oriented universities can set up cross-border e-commerce practice or other related courses based on the actual needs of foreign trade development, so that there isn't any innovation and practicability in the curriculum arrangement and teaching resources.

Emphasize theory teaching, while ignoring practical teaching. Currently, most business English teachers in application-oriented universities pay attention to the theory teaching, while ignoring business practical teaching, which lead to the weak practical ability of the students. In addition, many colleges and universities lack a complete and unified curriculum system of practical teaching. Some colleges even have neither practical teaching bases nor hardware and software infrastructure of practical teaching, and practical courses are carried out in theoretical teaching mode.

The rapid development of cross-border e-commerce has changed the modes and operations of the traditional trade. Under the transaction of cross-border e-commerce, there are great differences between cross-border e-commerce and traditional trade mode in marketing, payment, transportation, insurance, custom clearance, etc. For example, in terms of payment, cross-border e-commerce adopts more simple and fast payment mode, such as paypal or China's Alipay, instead of traditional payment, like L/C, D/P , T/T, etc. However, the textbook of international trade and practice has not been updated, and seldom involve the operation modes of cross-border e-commerce. Besides that, many teachers simply introduce the traditional trade mode and seldom impart cross-border e-commerce knowledge, which contribute to the disconnected of teaching contents and practical operation. Thus, business English talents can't fully satisfy the needs of cross-border e-commerce enterprises.

Lack of "Double-Professionally-Titled" Teachers. As a new undergraduate major, the construction of teacher team for business English has been relatively weak. Most business English teachers are young and middle-aged teachers with middle and lower professional post. And professional courses are usually taught either by teachers who major in English or teachers from relevant disciplines with a better command of English. However, most teachers do not have practical experience in business, and their knowledge structure is single, emphasizing books and theoretical knowledge. So they play a minor role in students' practice study. Besides, to most business English teachers, cross-border e-commerce is new knowledge, and itself is a learning process for teachers. Thus, it is difficult for teachers to give a comprehensive introduction on cross-border e-commerce in the short run. Anyhow, teachers in "dual quality" are generally scarce, so it is difficult to cultivate the qualified cross-border e-commerce talents. 


\section{The Strategies of Training Business English Talents for Cross-border E-commerce under the Background of "internet+"}

Build a New Curriculum System. Business English major should focus on construction of English and business course, and pay attention to the application of English language skill and business knowledge. In today's rapid development of electronic communications, the traditional business courses can not meet the needs of cross-border e-commerce development, and it's urgent to reform curriculum content and system. For example, in international trade practice, teachers should not only teach the traditional international trade mode, but also supplement the new trade mode - cross-border e-commerce, introducing the new business model and practical operation of cross-border e-commerce. Some application-oriented colleges shall set up courses, such as cross-border e-commerce, cross-border e-commerce practice. Besides, the establishment of cross-border e-commerce courses also needs to be closely integrated with real foreign trade projects, providing the real platform, product, process operation, so as to greatly improve students' learning initiative and professional skills. Furthermore, we should pay attention to the construction of the textbook of cross-border e-commerce, and choose the textbook with the real foreign trade program and written by teachers who have the real experiences of cross-border e-commerce.

Construct New Teaching Modes. Set up task-driving teaching mode. Task-based teaching must be student-centered and enable students to study with purpose, and it emphasizes the authenticity of teaching situation and the target of teaching. In the course of business English teaching, teachers can improve students' initiative and practical ability by designing various teaching tasks. For example, in the course of English Correspondence for Foreign Trade, through brainstorming, teacher shall introduce the basic writing knowledge, such as the writing skills, principles and main vocabulary, phrases, sentence patterns to the students before the task, Then combined with the real business situation, build a variety of letter writing tasks, such as inquiry, offer, counter-offer, acceptance, order, payment, shipment. After that, students plan the writing, then discuss in groups, compose and exhibit the writing in class. Finally, teacher carries on the analysis and the summary after students completing the letter writing task. Task-based teaching method not only greatly raises students' interest in learning, but also reflects the authenticity of the task and greatly improves students' practical ability.

Use the method of case teaching. Real cases can often arouse students' enthusiasm. In the context of cross-border e-commerce, it has spawned many new cases of international trade. In the classroom, teacher shall introduce new cases of cross-border e-commerce transaction and let students discuss the cases in group, which can greatly enhance students' learning interest. And students' learning purposes are more clearly.

Construct "flipped classroom" teaching model based on MOOC. In recent years, with the rapid development of network technology, the construction and application of MOOC (massive open online courses) has become very popular in educational circles at home and abroad. With its high-quality teaching resources, MOOC has aroused great concern of the higher education reformers in the era of digital information. Based on MOOC, FCM (flipped classroom) has deeply changed the traditional educational model. With the help of MOOC, we should let students learn knowledge autonomously after class, then teacher answer the questions and solve the problems in class. In this way, it will not only enable each student to personalize learning according to his learning ability and interest, but also increase the frequency and effect of practice training in classroom. Furthermore, we shall invite enterprises' professionals to join our business English teaching team, so as to carry out project-based teaching and build a special practice teaching course for cross-border e-commerce. Only in this way, can we improve the quantity and quality of business English practice in class and after class, and also cultivate compound applied and innovative talents for our society.

Improve the Quality of the Teaching Staff. Good teaching staff is the key to cultivate cross-border e-commerce talents. Application-oriented universities shall pay more attention to the cultivation of "double-professionally-titled" teachers for business English. For example, send young teachers to the cross-border e-commerce enterprises for a period of six months or a year's practice, 
or take the opportunity of summer vacation to be a trainee. In order to better guide the students' practical operation and become a truly "double qualified teachers", teacher shall participate in some professional training courses of Alibaba or other cross-border e-commerce enterprise, learn the operation of enterprises, know well the foreign trade process, and accumulate some related cases of cross-border e-commerce.

Construct Practice Bases. The application-oriented universities shall establish a school-enterprise cooperation model for cross-border e-commerce, which can not only provide practice base for study, but also benefit the construction of "double-professionally-titled" teaching staff. Under "mass entrepreneurship and innovation" circumstances, many colleges and universities around China have established various forms of college students pioneering park. Through the school-enterprise cooperation projects, we shall let our teachers and students involve in the operation platform of Aliexpress, ebay, Amazon,etc. Besides, we shall let the university and the enterprise jointly participate in the student's pre-employment training program. For example, our university is working with a cross-border e-commerce company to build an education demonstration base for innovation and entrepreneurship education, providing students with pre-employment skills training. And after mastering the latest workplace skills and cross-border practice, students will be more competitive to enter the workplace through short-term pre-employment skills training.

\section{Conclusion}

With the rapid development of cross-border e-commerce, enterprises have a growing demand for compound and applied talents who are not only proficient in English, but also understand foreign trade and the operation of e-commerce platform. Under the background of "internet +", application-oriented universities shall seize the opportunity to build a new training plan for cross-border e-commerce talents, strengthen the practice teaching and improve business English teaching staff, so as to cultivate the qualified compound and applied business English talents.

\section{Acknowledgment}

This study is supported by National College Students Innovation Experiment Project in 2017 (A survey of the development of cross-border e-commerce and the demand for business English talents in Xiangnan area under the "new normal" economy, item number 201710545004), the General Project of Hunan Social Science Achievements Review Committee in 2016(XSP2016W06), and Social Science Planning Project of Chenzhou in 2016(czssk12016059)

\section{References}

[1] ELT Advisory Board under the Ministry of Education. Several Opinions on the Reform of Undergraduate Education for Foreign Language Majors in Twenty-first Century(Shanghai foreign language education press, China 1998).

[2] Information on https://wenku.baidu.com/view/eaa348e04431b90d6d85c7ae.html, 2016.

[3] R. Li: Journal of Hubei Correspondence University, Vol. 25 (2012) No.9, p.129-130.

[4] Y. Wang: Journal of Liaoning Institute of Science and Technology, Vol. 18 (2016) No.2, p. 53-55.

[5] X.J. Sun: Journal of Hubei University of Economics (Humanities and Social Sciences), (2008) No.11, p.184-186.

[6] T.H. Lin: Journal of Guangdong university of foreign studies, Vol.21 (2010) No.4, p.15-21. 